\title{
Effectiveness of atrial versus atrioventricular pacing for sick sinus syndrome during long-term follow-up
}

\author{
Marcin Kuniewicz ${ }^{1,2}$, Anna Rydlewska ${ }^{1}$, Grzegorz Karkowski $^{1}$, Maria Lelakowska-Pieła $^{3}$, Jacek Majewski ${ }^{1}$, \\ Jacek Lelakowski ${ }^{1}$
}

'Department of Electrocardiology, Institute of Cardiology, Jagiellonian University, John Paul II Specialist Hospital, Krakow, Poland

${ }^{2}$ Chair and Department of Anatomy, Jagiellonian University Medical College, Krakow, Poland

${ }^{3}$ John Paul II Specialist Hospital, Krakow, Poland

\begin{abstract}
A b stract
Background: According to the current guidelines, atrioventricular (DDD) pacing is superior to atrial pacing (AAI) in the treatment of sick sinus syndrome (SSS).

Aim: To compare outcomes of AAI and DDD pacing in patients with SSS during long-term follow-up.

Methods: We studied 809 patients, including 86 patients in the AAI group (57 women, mean age $65 \pm 15$ years) and 723 patients in the DDD group (406 women, mean age $71.5 \pm 10$ years). Evaluation of outcomes of AAI and DDD pacing in SSS was based on the analysis of medical records of patients who underwent pacemaker implantation.

Results: Average duration of follow-up was $52 \pm 25$ months. In the AAI group, 63 of 86 patients remained without intervention. In the DDD group, 661 of 723 patients did not require surgical intervention. Overall, 105 patients died, including 13 in the AAI group and 92 in the DDD group $(p=0.4516)$. In the AAI group, a high degree atrioventricular block occurred on average after $46.3 \pm 8.8$ months and its incidence was estimated at $0.85 \%$ per year. Atrial fibrillation (AF) developed in 8 patients in the AAI group and 81 patients in the DDD group $(p=0.23)$. Among aetiological factors of an increased risk of developing $A F$, only the presence of tachycardia-bradycardia syndrome (hazard ratio [HR] 11.31) and the absence of antiarrhythmic therapy (HR 4.23) significantly increased the risk of AF. Urgent reoperation was needed in 23 patients in the AAI group and 62 patients in the DDD group $(\mathrm{p}<0.01)$. Log-rank test analysis showed a significant effect of the development of $\mathrm{AF}$ on the risk of reoperation in this group $(\mathrm{p}=0.0420)$. Lead-related complications were noted in 6 patients in the AAI group and 49 patients in the DDD group $(p=0.94)$. After 45 months, the risk of reoperation in the AAI group increased significantly due to a need for ventricular lead implantation.

Conclusions: 1. Atrial stimulation is safe in SSS but it may be associated with an increased risk of ventricular lead implantation if atrioventricular block or persistent AF with slow ventricular rate develops. 2. DDD and AAI groups did not differ significantly in terms of survival, development of persistent $\mathrm{AF}$, and lead-related complications. 3. Tachycardia-bradycardia syndrome and the lack of antiarrhythmic treatment with beta-blocker and amiodarone increased the risk of persistent AF during long-term follow-up. 4. A higher rate of reoperations in patients with AAI systems, related mainly to development of persistent AF, especially after the fourth year of follow-up, may justify DDD system implantation in SSS.
\end{abstract}

Key words: AAI pacing, DDD pacing, sick sinus syndrome

Kardiol Pol 2015; 73, 1: 7-16

\section{INTRODUCTION}

Sick sinus syndrome (SSS) is defined as a constellation of disturbances leading to inappropriate sinus rhythm rate which is too low for current physiologic needs, leading to symptoms and/or arrhythmia. Symptomatic treatment includes pacing and/or drug therapy. According to the current guidelines, dual

\footnotetext{
Address for correspondence:

Prof. Jacek Lelakowski, MD, PhD, Department of Electrocardiology, Institute of Cardiology, Jagiellonian University, John Paul II Specialist Hospital, ul. Prądnicka 80, 31-302 Kraków, Poland, tel: +48 1261422 77, fax: +48 1263323 99, e-mail: jlelakow@szpitaljp2.krakow.pl

Received: 02.11.2013 Accepted: 10.06.2014 Available as AoP: 04.07.2014

Copyright (C) Polskie Towarzystwo Kardiologiczne
} 
chamber pacing (DDD) with preserved native atrioventricular (AV) conduction to reduce the risk of atrial fibrillation (AF) and stroke, avoid pacing syndrome, and improve quality of life is preferred during invasive treatment of SSS (class I A recommendation), and atrial pacing (AAI) is second-line treatment (class I B recommendation) [1].

$\mathrm{AAI}$ pacing does not protect from $\mathrm{AV}$ block and slow ventricular rate in $\mathrm{AF}$, and thus patients are at risk of the same symptoms as in SSS.

Outcomes of AAI and DDD pacing were already compared in the literature but recent reports yielded inconsistent results. While Korean and Japanese registries, reported by Kim et al. [2] in 2010 and Masumoto et al. [3] in 2004, respectively, indicated that AAI pacing is the safest form of therapy in SSS, Nielsen et al. [4] in a 2011 report from the Danish DANPACE registry preferred DDD pacing as associated with lower rates of complications and reoperations (in line with the current 2013 guidelines) [1].

Thus, although DDD pacing in SSS in recommended in the current guidelines, comparisons of DDD and AAI pacing in SSS continue to be warranted in light of the reported contradictory results.

The aim of this study was to compare outcomes of AAI and DDD pacing in patients with SSS during long-term follow-up.

\section{METHODS}

We retrospectively analysed 3,140 patients with an implanted pacemaker (PM) who were under care of our centre (all implantations performed during the follow-up period).

The study group included patients following PM implantation due to SSS as documented by 12-lead electrocardiography (ECG) and/or 24-h Holter ECG monitoring and/or treadmill exercise test.

We excluded patients with paroxysmal second/third degree AV block, all forms of intraventricular conduction abnormalities (including left and right bundle branch block) with QRS duration > 120 ms, iatrogenic bradycardia, permanent $\mathrm{AF}$ and carotid sinus hypersensitivity before the procedure, low Wenckebach point $\leq 100 \mathrm{bpm}$, vascular anomalies, arrhythmias during the procedure, previous cardiac surgery, less than 3 follow-up visits, and incomplete pre- or postprocedural medical records. Patient groups selected using the above mentioned exclusion criteria are shown in Figure 1. Overall, we analysed 809 patients with AAI and DDD pacing and reliable source data including complete medical records.

Evaluation of outcomes of AAI and DDD pacing in SSS was based on the analysis of medical records of patients who underwent PM implantation, including records from at least 3 follow-up visits.

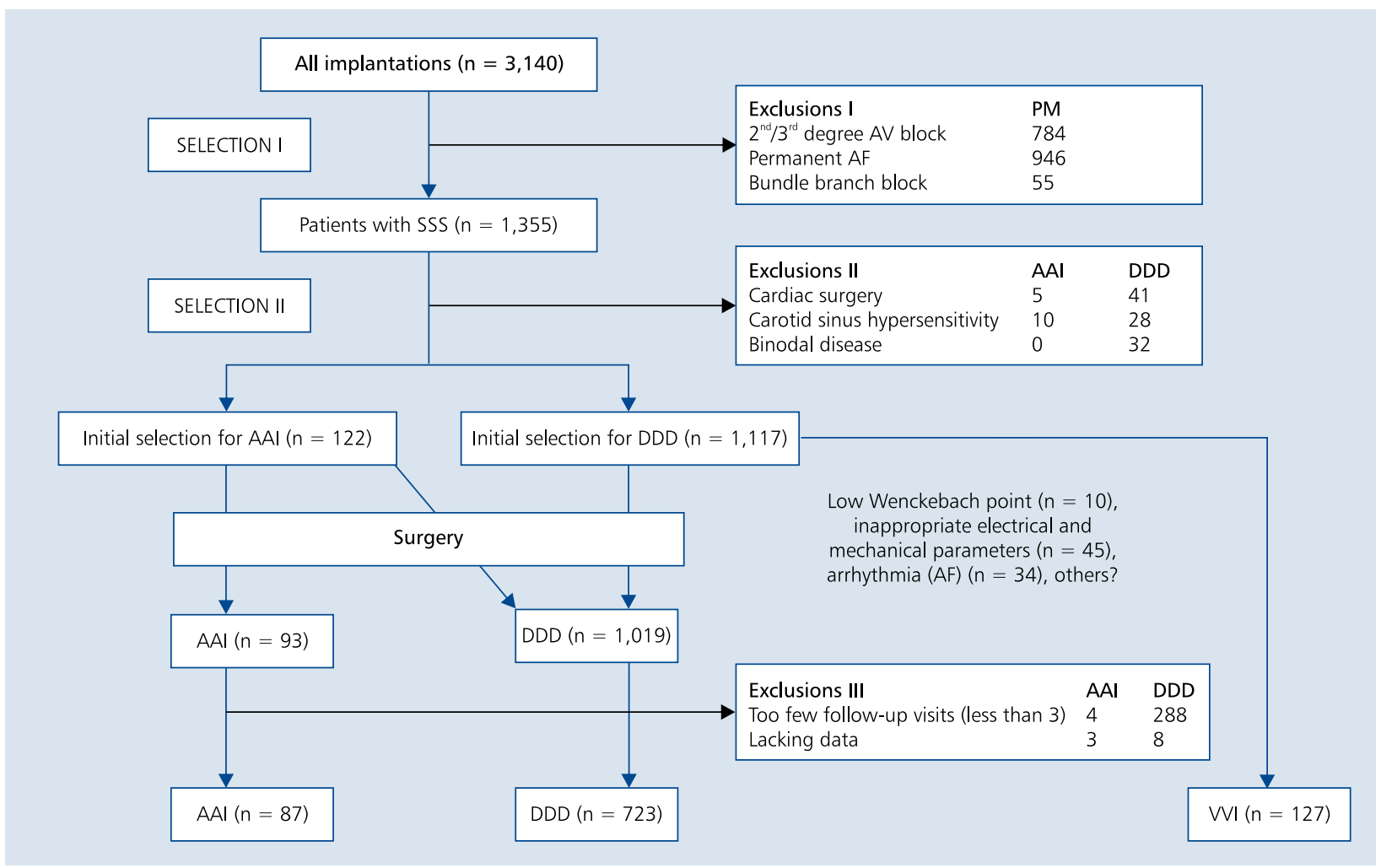

Figure 1. Patient selection flowchart; AF — atrial fibrillation; AV — atrioventricular; PM — pacemaker; SSS — sick sinus syndrome 
For the purpose of this analysis, we used data from:

- Preprocedural patient selection sheets;

- Device implantation protocols from the pacemaker IMPULS BIS database run by the Institute of Medical Technology and Equipment (ITAM) in Zabrze, Poland;

- ECGs recorded during the follow-up period;

- Outpatient records from the electronic patient database;

- Radiographs and their reports from the digital X-ray Netrad KSS JP2 database;

- Information about patient deaths from the PESEL database of the Ministry of Interior and Administration.

For patients included into the analysis, we recorded the following data:

- Personal data — gender, age, date of death;

- Date of implantation/reoperation;

- Types of pacing complications, their timing, and solutions;

- History of AF events and other arrhythmia episodes based on ECGs and PM mode at subsequent follow-up visits (but not based on the mode switch function);

- Concomitant diseases: hypertension, ischaemic heart disease, heart failure, diabetes, thyroid disease;

- Cardiovascular events;

- Cerebrovascular events;

- Information regarding anticoagulants (acenocoumarol, warfarin, heparin), antiplatelet drugs (aspirin, clopidogrel), and antiarrhythmic drugs (ajmaline, propafenone, mexiletine, sotalol, amiodarone, dronedarone, diltiazem, verapamil, beta-blockers) used after implantation.

Primary study endpoints included reoperation, death, occurrence of persistent $\mathrm{AF}$, and occurrence of a second or third degree AV block.

The diagnosis of permanent AF was made during subsequent follow-up visits when patient rhythm and timing of mode switch function activation (pacing mode switch from DDD to $\mathrm{VII}$ or $\mathrm{DDI}$ ) were evaluated.

First follow-up visits were at 1-2 months after the procedure, followed by 3-6 months after the procedure and 6-12 months thereafter. Pacing mode, pacing electrical parameters (native impulse, pacing threshold, and impedance), and capacity and internal resistance of the battery were evaluated by telemetry.

Twelve-lead ECGs at rest and after application of a magnet were performed in all patients.

The study was approved by a local bioethics committee (59/KBL/OIL/2012).

\section{Statistical analysis}

Quantitative and qualitative data were evaluated using descriptive statistics (range, mean, standard deviation, percentage distribution, $\chi^{2}$ test or exact Fisher test, Student $t$ test for independent samples or Mann-Whitney $U$ test, logistic regression).

Due to non-normal distribution of quantitative data, we used $\chi^{2}$ and log-rank tests to evaluate the risk of adverse events including reoperation, death, and occurrence of permanent AF. Cumulative survival function was interpreted graphically using the Kaplan-Meier curve. We used a log-rank test to verify the null hypothesis of no significant difference in survival between the groups. Then, we used a Cox model to analyse potential factors that might affect occurrence of AF. We calculated $\beta_{0^{\prime}} \beta$, odds ratio (OR) and hazard ratio (HR) values, and their corresponding 95\% confidence intervals.

Results were considered significant when $\mathrm{p}$ was less than the significance level of $\alpha=0.05$.

Statistical analysis was performed using the Statistica 10 PL software (StatSoft Poland).

\section{RESULTS}

The study group of 809 patients with an implanted PM (463 women, 346 men, mean age $70 \pm 11$ years, range 19-95 years) was selected from 1,355 patients with SSS remaining under the care of our centre, as show in Figure 1. The AAI pacing group included 86 patients ( 57 women, 29 men, mean age $65 \pm 15$ years range $19-81$ years), and the DDD pacing group included 723 patients (406 women, 317 men, mean age $71.5 \pm 10$ years, range $23-95$ years). Minimal duration of follow-up was 11 months (with at least 3 follow-up visits during this period), maximum duration of follow-up was 101 months, and mean duration of follow-up was $52 \pm 25$ months (AAI group: $65 \pm 27$ months; DDD group: $50 \pm 24$ months). Patient characteristics are shown in Table 1.

During mean $4.3 \pm 2.1$ years of follow-up, more than $89.5 \%$ of 809 de novo implanted PMs functioned without complications or a need for urgent reoperation. No surgical intervention was required in 63 (73\%) of 86 implanted PMs in the AAI group and in 661 (91\%) of 723 PMs in the DDD group.

Overall, 105 (13\%) patients died, including $13(15.1 \%)$ in the AAI group and $92(12.7 \%)$ in the DDD group $(p=0.4516)$. Mortality in the two groups is shown in Figure 2. The mean annual mortality was $2.79 \%$ in the AAI group and $3.05 \%$ in the DDD group $(p=0.53)$.

In the AAl group ( $n=86$ ), AV block occurred in 4 patients at mean $46.3 \pm 8.8$ months after PM implantation. The risk of AV block was $0.86 \%$ per year and was apparent in all age groups, as the youngest patient with AV block was 27 years old, and the oldest was 78 years old (mean age $55.5 \pm 17.3$ years). In all these patients, a ventricular lead was added. Follow-up evaluations did not include AV conduction in patients with DDD systems. Permanent AF developed in 8 (9.3\%) patients in the AAI group and in 81 (11.2\%) patients in the DDD group ( $p=0.2259)$, as shown in Figure 3 .

Overall, the mean time from PM implantation to development of permanent AF was $31.5 \pm 22$ months (AAI group $41 \pm 33$ months, DDD group $31 \pm 21$ months). Patients with tachycardia-bradycardia syndrome developed permanent AF at $29.6 \pm 20$ months, and de novo development of permanent AF occurred at $41 \pm 29$ months ( $p<0.01)$. Annual incidence 
Table 1. Characteristics of the study patients

\begin{tabular}{|c|c|c|c|c|}
\hline Patient characteristics & $\mathrm{AAI}(n=86)$ & $\mathbf{P}$ & $\operatorname{DDD}(n=723)$ & Overall $(n=809)$ \\
\hline Women & $57(66.30 \%)$ & 0.072 & $406(56.15 \%)$ & $463(57.23 \%)$ \\
\hline Age & $65 \pm 15.00$ & $<0.01$ & $71 \pm 10.1$ & $70 \pm 11$ \\
\hline Tachycardia-bradycardia syndrome & $17(19.77 \%)$ & $<0.01$ & $374(51.73 \%)$ & $391(48.33 \%)$ \\
\hline Arterial hypertension & $61(70.93 \%)$ & $<0.01$ & $618(85.48 \%)$ & 679 (83.93\%) \\
\hline Ischaemic heart disease & $44(51.16 \%)$ & 0.049 & $449(62.10 \%)$ & $493(60.94 \%)$ \\
\hline Diabetes & $12(13.95 \%)$ & 0.42 & $126(17.43 \%)$ & $138(17.06 \%)$ \\
\hline Transient ischaemic attack & $1(1.16 \%)$ & 0.86 & $10(1.38 \%)$ & $11(1.36 \%)$ \\
\hline Stroke & $1(1.16 \%)$ & 0.72 & $12(1.66 \%)$ & $13(1.61 \%)$ \\
\hline Heart failure & $9(10.47 \%)$ & 0.22 & $111(15.35 \%)$ & $120(14.83 \%)$ \\
\hline Supraventricular ectopic beats & $2(2.33 \%)$ & 0.05 & $59(8.16 \%)$ & $61(7.54 \%)$ \\
\hline Ventricular ectopic beats & $4(4.65 \%)$ & $<0.01$ & $127(17.56 \%)$ & $131(16.19 \%)$ \\
\hline Myocardial infarction & $9(10.47 \%)$ & 0.39 & $100(13.83 \%)$ & $109(13.47 \%)$ \\
\hline Thyroid disease (hyper-/hypothyroidism) & $11(12.79 \%)$ & 0.72 & $83(11.48 \%)$ & $94(11.62 \%)$ \\
\hline Drug-induced bradycardia & $0(0.00 \%)$ & 0.11 & $21(2.90 \%)$ & $21(2.90 \%)$ \\
\hline Syncope & $39(45.35 \%)$ & 0.03 & $417(57.68 \%)$ & $456(56.36 \%)$ \\
\hline MAS attack & $20(23.26 \%)$ & 0.17 & $125(17.29 \%)$ & $145(17.92 \%)$ \\
\hline ASA & $53(61.63 \%)$ & 0.08 & $373(51.59 \%)$ & $426(52.66 \%)$ \\
\hline Clopidogrel & $0(0.00 \%)$ & 0.55 & $3(0.41 \%)$ & $3(0.37 \%)$ \\
\hline ASA + clopidogrel & $1(1.16 \%)$ & 0.75 & $6(0.83 \%)$ & $7(0.86 \%)$ \\
\hline Acenocoumarol & $7(8.14 \%)$ & $<0.01$ & $185(25.59 \%)$ & $192(23.73 \%)$ \\
\hline LMWH & $2(2.33 \%)$ & 0.36 & $32(4.43 \%)$ & $34(4.20 \%)$ \\
\hline Beta-blocker & $35(40.69 \%)$ & 0.03 & $470(65.00 \%)$ & $505(62.42 \%)$ \\
\hline Antiarrhythmic drugs (class I, III, IV) & $14(16.27 \%)$ & $<0.01$ & $320(44.26 \%)$ & $334(41.28 \%)$ \\
\hline Other antiarrhythmic drugs & $10(11.62 \%)$ & $<0.01$ & 301 (41.63\%) & 311 (38.44\%) \\
\hline
\end{tabular}

ASA — acetylsalicylic acid; LMWH — low molecular weight heparin; MAS — Morgagni-Adams-Stokes

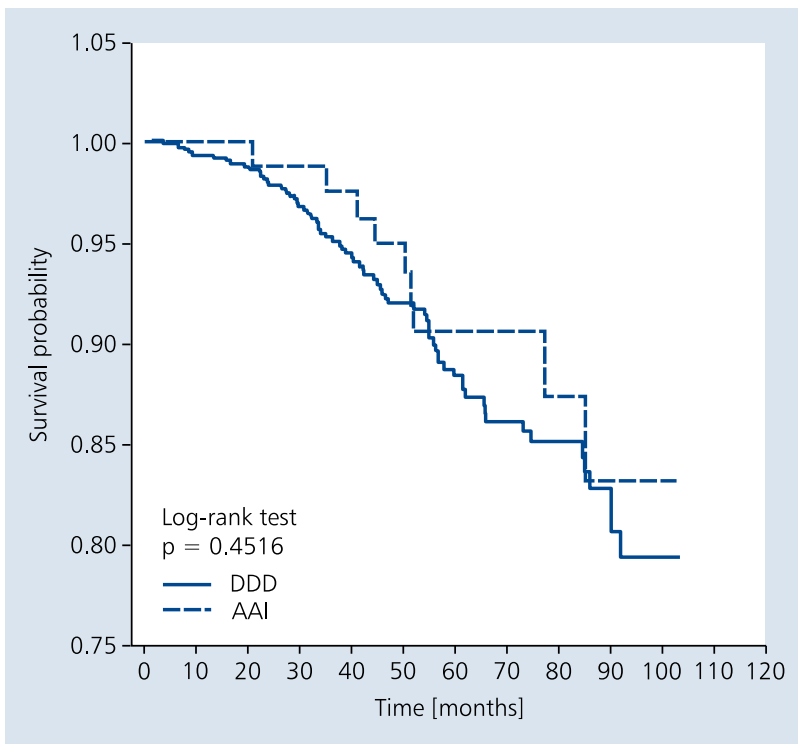

Figure 2. Survival after pacemaker implantation (DDD/AAI)

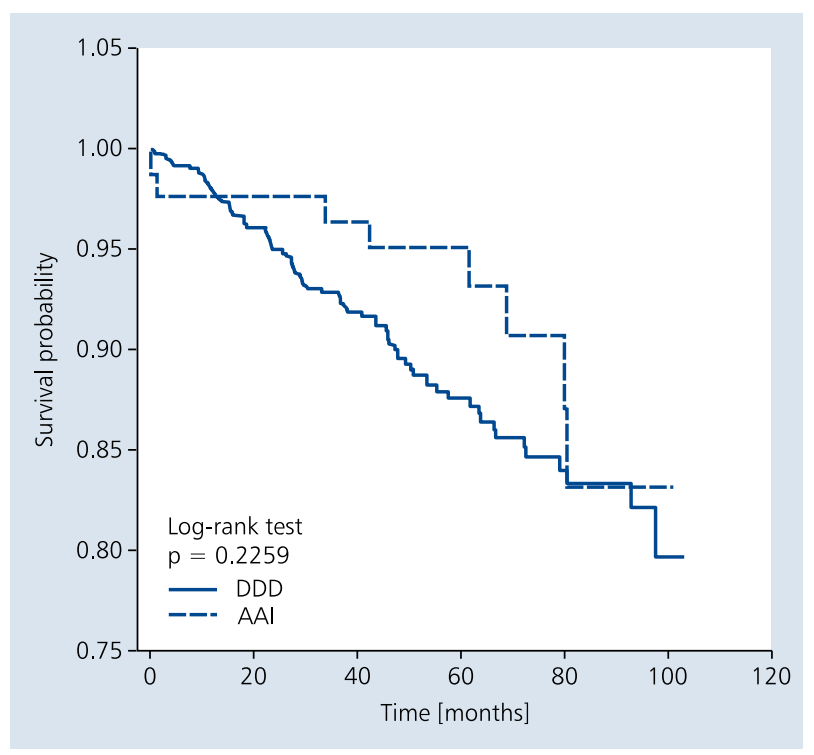

Figure 3. Survival free from atrial fibrillation in both study groups (AAI/DDD) 


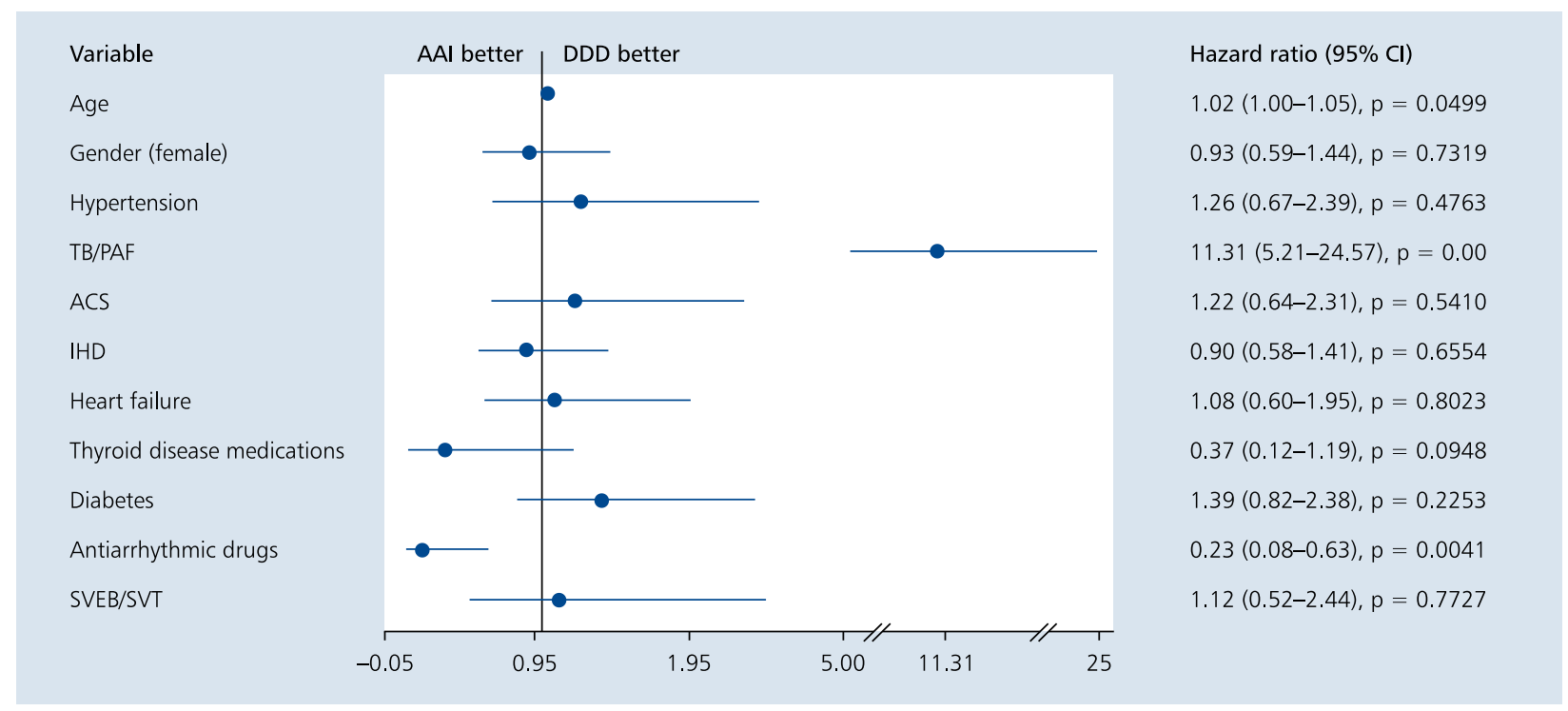

Figure 4. Predictors of atrial fibrillation - hazard ratios with 95\% confidence intervals $(\mathrm{Cl})$ and $\mathrm{p}$ values; ACS — acute coronary syndrome; IHD — ischaemic heart disease; SVEB/SVT — supraventricular ectopic beats/supraventricular tachycardia;

$\mathrm{TB} / \mathrm{PAF}$ — tachycardia-bradycardia syndrome/paroxysmal atrial fibrillation

Table 2. Cox model results for tachycardia-bradycardia syndrome as a predictor of atrial fibrillation after pacemaker implantation

\begin{tabular}{|lc|}
\hline Beta & 2.4258 \\
Standard error & 0.3958 \\
Beta lower 95\% confidence limit & 1.6499 \\
Beta upper 95\% confidence limit & 3.2016 \\
T & 6.1282 \\
Wald statistic & 37.5546 \\
P & 0.00 \\
Hazard ratio (HR) & 11.3110 \\
HR lower 95\% confidence limit & 5.2067 \\
HR upper 95\% confidence limit & 24.5719 \\
\hline
\end{tabular}

of $\mathrm{AF}$ was $1.72 \%$ in the $\mathrm{AAI}$ group and $2.7 \%$ in the DDD group. Patients in the DDD group with right ventricular apex (RVA) lead developed permanent AF at a rate of 3.33\% per year vs. $2.5 \%$ per year in those with right ventricular outflow tract (RVOT) lead ( $p=0.317$ ). Unfortunately, due to a retrospective nature of our study we were unable to evaluate the percentage of ventricular pacing in the DDD group.

When we evaluated the presence of a first degree AV block, which was not an exclusion criterion for the DDD group $(\mathrm{n}=723)$, a Cox proportional hazard model indicated that the development of a first degree AV block had no significant effect ( $p=0.3016$ ) on the time to AF occurrence.

Antiarrhythmic drug therapy is a factor protecting from the development of permanent AF. In monotherapy, best outcomes were noted for bisoprolol $(p<0.01)$ but the best protection from the development of permanent AF was af-
Table 3. Cox model results for lack of antiarrhythmic treatment as a predictor of atrial fibrillation after pacemaker implantation

\begin{tabular}{|lc|}
\hline Beta & 1.472 \\
Standard error & 0.5129 \\
Beta lower 95\% confidence limit & 2.477 \\
Beta upper 95\% confidence limit & 0.466 \\
T & 2.869 \\
Wald statistic & 8.2368 \\
P & 0.00 \\
Hazard ratio (HR) & 4.2345 \\
HR lower 95\% confidence limit & 2.2334 \\
HR upper 95\% confidence limit & 6.4325 \\
\hline
\end{tabular}

forded by a combination of a long-acting beta-blocker and amiodarone $(p<0.01)$ which significantly prolonged the time from PM implantation to development of AF. Other upstream treatment was not analysed.

Among eatiological factors of an increased risk of developing permanent AF (age, gender, tachycardia-bradycardia syndrome, supraventricular extrasystoles, lack of antiarrhythmic treatment, thyroid disease, ischaemic heart disease, hypertensive heart disease, heart failure, first degree AV block), only the presence of tachycardia-bradycardia syndrome (HR 11.31) and the absence of antiarrhythmic therapy (HR 4.23) was shown to significantly increase the risk of AF. Predictors of an increased risk of AF development are shown in Figure 4 and in Tables 2 and 3.

In the AAI group, reoperation was performed in 23 (26.7\%) patients compared to $62(8.57 \%)$ patients in the DDD group 


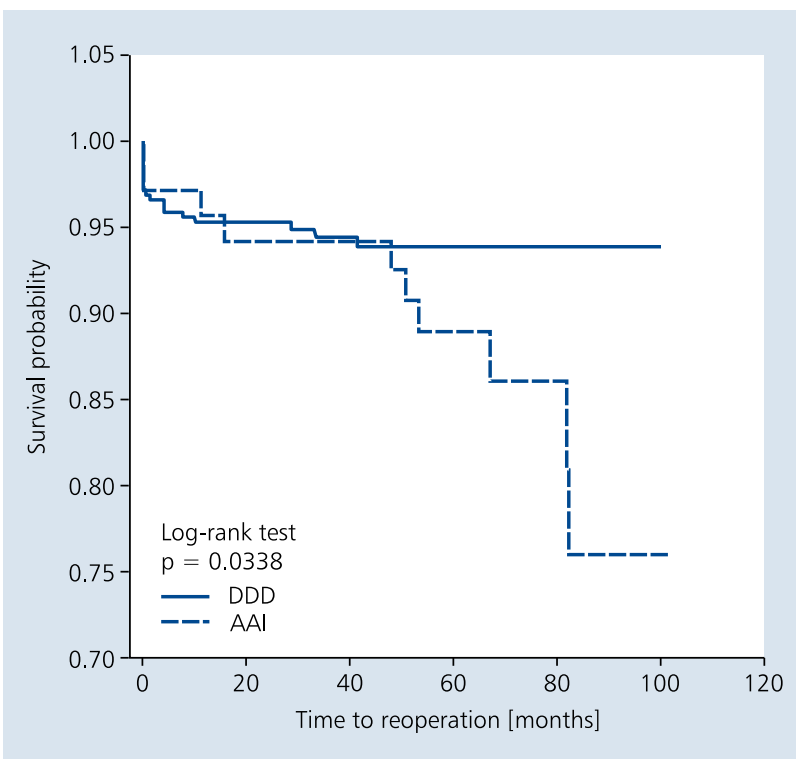

Figure 5. Survival free from reoperation in both study groups (AAI/DDD)

$(p<0.01)$. Time to reoperation differed significantly differed significantly between the DDD and AAI groups ( $p=0.0338$, log-rank test). In the DDD group, the likelihood of survival without reoperation remained constant, while it decreased with time in the AAI group. This was particularly seen after 45 months, when the risk of reoperation in the AAI group rose sharply due to the need of ventricular lead insertion. The likelihood of survival free from reoperation is shown in Figure 5.

Surgical change of the mode of pacing from AAI to $\mathrm{VVI}$ due to permanent AF was performed in $13(15 \%)$ patients, and from DDD to VVI in $1(0.14 \%)$ patient $(p<0.01)$. The mean time from PM implantation to surgical change in the mode of pacing was $46.7 \pm 25.2$ months. In the remaining 47 cases when mode of pacing had to be switched from DDD to $\mathrm{VII}(\mathrm{R})$, this was performed using a remote programming device and reoperation was not necessary.

In the AAl group, the need to insert a ventricular lead due to development of AF leading to clinical symptoms of bradycardia (pauses $>3 \mathrm{~s}$, minimal heart rate $<30 \mathrm{bpm}$, dizziness) occurred at a rate of $1.72 \%$ per year. Log-rank test analysis showed a significant effect of the development of AF on the risk of reoperation in this group $(p=0.0420)$. The likelihood of survival free from reoperation and development of permanent AF in the AAI group is shown in Figure 6.

Lead-related complications (lead displacement, lead damage, exit block) were noted in 6 (6.9\%) patients in the AAI group and in $49(6.7 \%)$ patients in the DDD group $(p=0.94)$. Overall, complications were more frequent in the AAI group than in the DDD group $(26.7 \%$ vs. $8.57 \%$, p < 0.01$)$, as shown in Table 4.

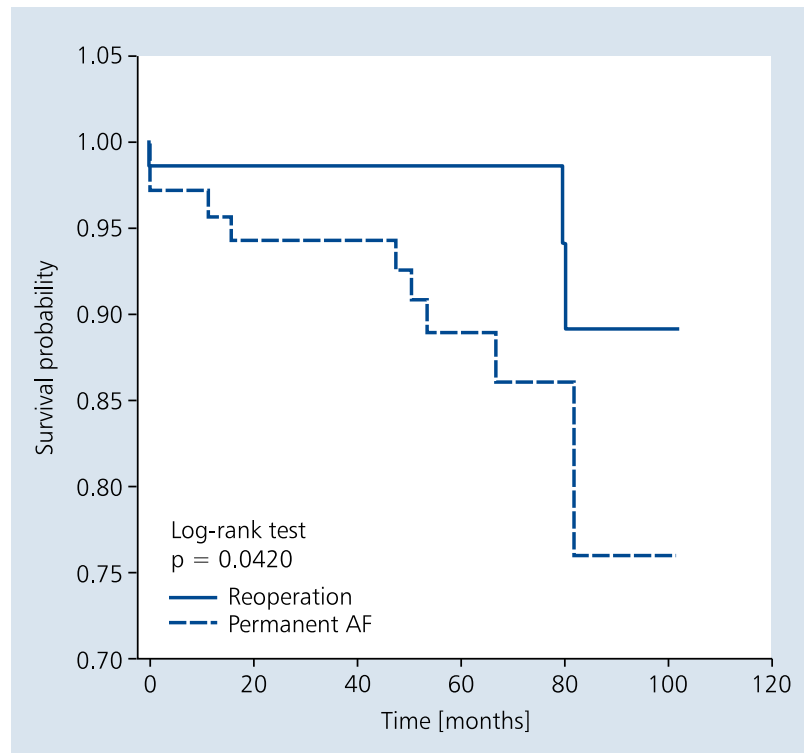

Figure 6. Survival free from reoperation and development of permanent atrial fibrillation (AF) in the AAl group

\section{DISCUSSION}

Many reports have been published in the literature regarding the effectiveness of pacing therapy in SSS, rates and types of complications, and mortality after PM implantation. These were often multicentre analyses leading to new management algorithms and new guidelines, and sometimes only summaries of alternative approaches to pacing in SSS [2-8]. Until now, no other study summarised such a long-term patient follow-up, mean 4.3 years (with the longest follow-up duration of 8 years), in the invasive treatment of SSS, comparing the effectiveness of AAI and DDD pacing. We were also motivated to perform this comparison due to the fact that atrial pacing systems are currently implanted in a small minority of patients with SSS and are not considered treatment of choice. Thus, we wanted to reevaluate the usefulness of AAI pacing in SSS based on our own experience.

Since 1997, after the era of comparisons of single chamber atrial (AAI) vs. single chamber ventricular (VVI) pacing, AAI pacing became to be compared in the literature with dual chamber pacing (DDD) which started to be more commonly used. Initial comparative studies showed superiority of AAI pacing as a more physiologic approach preserving native AV conduction [5, 6] in patients with SSS. This was confirmed in the studies by Morínigo et al. [7], Masumoto et al. [3], Tripp et al. [8], and Kim et al. [2], until results of the Danish DANPACE registry were reported in 2011 [4], overturning previous beliefs about superiority of AAI pacing. The latter was shown not to protect from bradycardia due to AV block or AF with slow ventricular rate, putting patients at an increased risk of reoperation. 
Table 4. Summary of complications of cardiac electrotherapy and the need for reoperation

\begin{tabular}{lccccc} 
Complications & AAl & DDD & $\mathbf{P}$ & Overall & $\begin{array}{c}\text { Not requiring } \\
\text { reoperation }\end{array}$ \\
\hline Lead displacement & $3(3.49 \%)$ & $23(3.18 \%)$ & 0.88 & $26(3.21 \%)$ & 0 \\
Lead damage & $1(1.16 \%)$ & $6(0.83 \%)$ & 0.75 & $7(0.87 \%)$ & 1 \\
Exit block & $2(2.33 \%)$ & $14(1.94 \%)$ & 0.80 & $16(1.98 \%)$ & 3 \\
Change of pacing mode & $13(15.12 \%)$ & $1(0.14 \%)$ & $<0.01$ & $14(1.73 \%)$ & 0 \\
Inappropriate pacemaker function & $0(0 \%)$ & $2(0.28 \%)$ & 0.62 & $2(0.25 \%)$ & 0 \\
Pneumothorax & $1(1.16 \%)$ & $3(0.41 \%)$ & 0.35 & $4(0.49 \%)$ & 0 \\
Pocket hematoma & $2(2.33 \%)$ & $2(0.28 \%)$ & 0.01 & $4(0.49 \%)$ & 0 \\
Muscle stimulation & $0(0 \%)$ & $3(0.41 \%)$ & 0.55 & $3(0.37 \%)$ & 1 \\
Pocket mechanical trauma & $1(1.16 \%)$ & $2(0.28 \%)$ & 0.20 & $3(0.37 \%)$ & 0 \\
Myocardial perforation & $0(0 \%)$ & $3(0.41 \%)$ & 0.55 & $3(0.37 \%)$ & 0 \\
Venous occlusion & $0(0 \%)$ & $2(0.28 \%)$ & 0.62 & $2(0.25 \%)$ & 1 \\
Pocket infection & $0(0 \%)$ & $1(0.14 \%)$ & 0.73 & $1(0.12 \%)$ & 0 \\
Overall & $23(26.7 \%)$ & $62(8.57 \%)$ & $<0.01$ & $85(10.5 \%)$ & 6 \\
\hline
\end{tabular}

Despite many multicentre trials published during the last 15 years, many questions remain unanswered. It is still not clear what the long-term clinical effectiveness of DDD and $\mathrm{AAI}$ pacing is in the Polish population of patients with SSS. Specifically, it is not known whether complication rates, mortality and the development of AF are similar in patients treated with these two pacing modes.

\section{Atrioventricular block}

The development of a high-degree AV block must be considered when comparing advantages and disadvantages of AAI and DDD pacing in patients with SSS. In our study, 4 patients in the AAI group required implantation of an additional ventricular lead due to development of a symptomatic second degree AV block. The rata of the latter was calculated at $0.85 \%$ per year and is comparable to the rates reported in the literature $[9,10]$. Of note, none of our patients developed significant bradycardia that would require urgent surgical intervention. Timing of conversion from AAI to DDD pacing is still a matter of debate. Rosenqvist et al. [11] highlighted that asymptomatic episodes of a high-degree AV block may reflect changes in the autonomic nervous system and not degenerative changes in the AV node itself, as evidenced by an intermittent nature of the block, occurring mostly during the night. In addition, the most common cause of AV conduction disturbances is drug therapy and not degenerative changes in the cardiac conduction system [12].

\section{Atrial fibrillation}

Atrial fibrillation is one of long-term complications of sinus node dysfunction. Historically, in regard to the development of $\mathrm{AF}$, comparisons of $\mathrm{AAI}$ and DDD pacing were always favouring the former, starting from the 2003 study by Moriñigo et al. [7] in 177 patients (with AF developing in $7.4 \%$ patients in the AAI group and $23 \%$ patients in the DDD group), through the studies by Masumoto et al. [3] (AF in $4.2 \%$ patients in the AAI group and $8 \%$ patients in the DDD group) and Tripp et al. [8] (AF in 2.8\% patients in the AAI group and 15.2\% patients in the DDD group), until the DANPACE study in 2011 showed for the first time that the proportion of patients developing AF was higher in the AAI group than in the DDD group ( $28.4 \%$ vs. $23 \%$, respectively). In the latter study, more frequent occurrence of $\mathrm{AF}$ in the AAI group was thought to be due to a prolonged AV conduction time with pacing from the right atrial appendage. In this scenario, ventricular preload is reduced, increasing diastolic backward flow through the mitral valve and thus leading to an increased risk of AF. It was shown that the rate of $A F$ increases when the $P R$ interval is $>180 \mathrm{~ms}$ [13]. In our study population, overall rate of permanent AF was $11 \%(9.3 \%$ in the AAl group and $11.2 \%$ in the DDD group), with no significant difference between the two groups by log-rank test. The mean time to the development of AF was $31.5 \pm 22$ months and was notably shorter in patients with tachycardia-bradycardia syndrome (29.6 \pm 20 months) than in patients developing AF de novo (41 \pm 29 months). In addition, tachycardia-bradycardia syndrome was shown to be a significant predictor of the development of AF. In our study, we did not consider the rate of ventricular pacing due to a retrospective nature of this analysis. To evaluate the rate of $\mathrm{AF}$ in the $\mathrm{AAl}$ group, our results may be compared with the results of a 5.4-year follow-up of patients with AAI pacing systems reported by Moriñigo et al. [7]. The latter study was performed in a similar patient population in regard to the mean age, gender, and concomitant diseases. The rate of AF was $10 \%$, and thus it was comparable to the rate reported in the present study. 
Is the development of $\mathrm{AF}$ an absolute indication for implantation of an additional lead in AAl systems? The study by Masumoto et al. [3] showed that even in patients with AAI systems who developed chronic $\mathrm{AF}$, it was not necessary to implant an additional ventricular lead to treat bradycardia. Andersen et al. [14] also arrived at similar conclusions. In our study group, AF with symptomatic bradycardia was one of the major causes of reoperation in the AAI group and change of the pacing mode in the DDD group. Perhaps our approach was too cautious as none of the studied patients developed full-blown syncope despite significant bradycardia. Practice indicates that decisions to implant a PM in permanent $\mathrm{AF}$ are very often arbitrary and this treatment may be overused. As reoperation is performed in about $15 \%$ of patients with an AAI system, these decisions have a significant effect on the results of clinical observations. On the other hand, these decisions reflect everyday clinical practice.

\section{Selected factors predisposing to the development of $A F$}

In a Cox model, among potential factors affecting development of permanent AF (ventricular lead location, presence of tachycardia-bradycardia syndrome, first degree AV block, concomitant thyroid disease, supraventricular extrasystoles, ischaemic heart disease, hypertensive heart disease, heart failure, lack of antiarrhythmic treatment), only the presence of tachycardia-bradycardia syndrome and lack of antiarrhythmic treatment after PM implantation were shown to be significant predictors of AF. The best combination of antiarrhythmic drugs offering protection from AF was that of a beta-blocker and amiodarone.

The above mentioned tachycardia-bradycardia syndrome, i.e. paroxysmal AF preceded by sinus bradycardia, was the most significant factor affecting the development of permanent $\mathrm{AF}$, more important that the lack of AV synchrony in a third degree AV block [15].

In our study, we were unable to confirm an effect of a first degree AV block (PR interval $200 \mathrm{~ms}$ ) on the rate of AF. In contrast, the DANPACE study showed that the PR interval $\geq 180 \mathrm{~ms}$ predisposed to the development of $A F$ [13]. Thus, DDD pacing protects patients from the development of AF. In our earlier observations, we showed that abrupt prolongation of the PR interval occurred at the age of 61-70 years, mostly in those patients in whom the mean preimplantation PR interval was 196 ms [16]. Those patients were at an increased risk of AF development and reoperation. In the current analysis, likely due to a low number of patients in the AAI group $(n=86)$, we were unable to confirm the results of DANPACE study. Similarly, ventricular lead location (RVOT vs. RVA, $p=0.317)$ and age $(p=0.078)$ had no significant effect on the development of $A F$, although the mean age of patients with AF was more than 2 years higher compared to patients without AF $[17,18]$. In our opinion, this may be attributed to the selection of patients. In the study by Majewski et al. [19], evaluating durability of DDD pacing, 3 factors were shown to significantly affect AF development, including SSS, tachycardia-bradycardia syndrome and age. Of note, however, the mean patient age in that analysis was more than 5 years lower that in the present study.

\section{Selected lead-related complications}

Damage of an intracardiac lead is one of the most important complications during long-term follow-up after PM implantation. The relative risk of lead damage and failure to pace with DDD systems is estimated to be increased 2.045 times compared to AAI pacing, due to a twice higher number of implanted pacing leads. Hauser et al. [20] noted a $6 \%$ rate of ventricular lead damage during 5 years of dual chamber pacing. Helguera et al. [21] concluded that in older patients ( $>65$ years), atrial leads were characterised by a much lower rate of verified malfunctions. The number of indwelling leads is also important. Each reoperation is associated with an approximately $2 \%$ risk of infection, and the latter is an indication for complete pacing system removal [22]. In our study population, lead-related complications were among the most common causes for reoperation but unlike other authors, we did not find a difference in their rate depending on pacing mode ( $7 \%$ in the AAI group vs. $6 \%$ in the DDD group). This observation is in favour of DDD pacing and does not support the conclusion that DDD pacing is associated with a twice higher rate of lead-related complications, as these are mostly related to atrial leads $(88.46 \%$ of all lead-related complications). Obviously, we are aware that the number of implanted AAl systems $(n=86)$ was relatively small. The rate of other complication is comparable to that reported in other centres, ranging from $10.1 \%$ [23] to $12.4 \%$ [24].

\section{Limitations of the study}

Our study was a nonrandomised, retrospective, single-centre observation that included a relatively low number of patients with atrial pacing. The results might have also been affected by the inclusion/exclusion criteria used in our study, specifically the need for complete procedural and long-term follow-up records for a patient to be included in the analysis.

\section{Summary}

During mean 4.3 years of follow-up of 809 patients with a de novo implanted PM, more than $89.5 \%$ of these devices functioned without complications or the need for reoperation. We did not show significant differences between the DDD and AAI groups in terms of survival, development of persistent $\mathrm{AF}$, and lead-related complications although the two groups differed in age (by about 6 years) and the severity of concomitant conditions. Specifically, patients in the DDD group were older and more often had tachycardia-bradycardia syndrome, ventricular ectopy, paroxysmal supraventricular 
arrhythmias, heart failure, ischaemic heart disease, diabetes, and arterial hypertension. Beyond 4 years of use, the AAI system becomes unstable (with a significant increase in the reoperation rate) and thus the proportion of AAI systems without the need for intervention is smaller (73\%) compared to DDD systems (91\%).

In summary, our observations favour DDD and not AAI pacing in the treatment of SSS. These findings are in agreement with the current 2013 recommendations on the choice of pacing mode in patients with dysfunction of sinus node automaticity [1].

\section{CONCLUSIONS}

1. Atrial stimulation is safe in SSS but associated with an increased risk of ventricular lead implantation due to development of AV block or persistent AF with AV conduction disturbances.

2. DDD and AAI groups did not differ significantly in terms of survival, development of persistent $\mathrm{AF}$, and lead-related complications.

3. Tachycardia-bradycardia syndrome and the lack of antiarrhythmic treatment were associated with an increased risk of persistent AF during long-term follow-up.

4. Due to a higher rate of reoperations in patients with AAI systems, related mainly to development of persistent $A F$, especially after the fourth year of follow-up, DDD system implantation in SSS may be of more benefit.

\section{Conflict of interest: none declared}

\section{References}

1. Brignole M, Auricchio A, Baron-Esquivias G et al. 2013 ESC Guidelines on cardiac pacing and cardiac resynchronization therapy. Eur Heart J, doi:10.1093/eurheartj/eht150.

2. Kim WH, Joung B, Shim J et al. Long-term outcome of single-chamber atrial pacing compared with dual-chamber pacing in patients with sinus-node dysfunction and intact atrioventricular node conduction. Yonsei Med J, 2010; 51: 832-837.

3. Masumoto H, Ueda Y, Kato R et al. Long-term clinical performance of AAI pacing in patients with sick sinus syndrome: a comparison with dual-chamber pacing, Europace, 2004; 6: 444-450.

4. Nielsen JC, Thomsen PE, Højberg S et al. DANPACE investigators. A comparison of single-lead atrial pacing with dual-chamber pacing in sick sinus syndrome. Eur Heart J, 2011; 32: 686-696.

5. Vardas P, Simantirakis E, Parthenakis F et al. AAIR versus DDDR pacing in patients with impaired sinus node chronotropy: an echocardiographic and cardiopulmonary study. Europace, 2004; 6: 444-450.

6. Schwaab B, Kindermann M, Schatzer-Klotz D et al. AAIR versus DDDR pacing in the bradycardia tachycardia syndrome: a prospective, randomized, double-blind, crossover trial. Pacing Clin Electrophysiol, 2001; 24: 1585-1595.

7. Morínigo JL, Arribas A, Ledesma C et al. Clinical safety and efficacy of single-chamber atrial pacing in sick sinus syndrome: long-term follow-up. Rev Esp Cardiol, 2002; 55: 1267-1272.
8. Tripp IG, Armstrong GP, Stewart JT et al. Atrial pacing should be used more frequently in sinus node disease. Pacing Clin Electrophysiol, 2005; 28: 291-294.

9. Irwin M, Cabrol B, Zenaratne $\mathrm{M}$ et al. Long-term survival of chosen atrial-based pacing modalities. Pacing Clin Electrophysiol, 1996; 19: 1796-1798.

10. Kristensen L, Nielsen JC, Pedersen AK et al. AV block and changes in pacing mode during long-term of 399 consecutive patients with sick sinus syndrome treated with an AAI/AAIR pacemaker. Pacing Clin Electrophysiol, 2001; 24: 358-365.

11. Rosenquist M, Obel IWP. Atrial pacing and the risk for AV block: is there a time for change in attitude? Pacing Clin Electrophysiol, 1989; 12: 97-101.

12. Bohm A, Printer A, Szeklely A et al. Clinical observations with long-term atrial pacing. Pacing Clin Electrophysiol, 1998; 21: 246-249.

13. Nielsen JC, Thomsen PE, Højberg S et al. DANPACE investigators. Atrial fibrillation in patients with sick sinus syndrome: the association with PQ-interval and percentage of ventricular pacing. Europace, 2012; 14: 682-689.

14. Andersen HR, Nielsen JC, Thomsen PE et al. Long-term follow-up of patients from a randomized trial of atrial versus ventricular pacing for sick-sinus syndrome. Lancet, 1997; 350: 1210-1216.

15. Matusik P, Woźnica N, Lelakowski J. Migotanie przedsionków przed implantacją rozrusznika serca (VVI i DDD) i po zabiegu u chorych z całkowitym blokiem przedsionkowo-komorowym. Pol Merk Lek, 2010; 167: 345-347.

16. Szczechowicz M, Wilczek U, Lelakowski J. Ryzyko wystapienia bloku przedsionkowo-komorowego pierwszego stopnia w czasie stymulacji przedsionkowej w zespole chorego węzła zatokowego. Przegl Lek, 2010; 67: 157-160.

17. Hong-Xiang Z, Jun Q, Fa-Qin H, et al. Comparison of right ventricular apex and right ventricular outflow tract septum pacing in the elderly with normal left ventricular ejection fraction: long-term follow-up. Kardiol Pol, 2012; 70: 1130-1139.

18. Lewicka-Nowak E, Dąbrowska-Kugacka A, Tybura S et al. Right ventricular apex versus right ventricular outflow tract pacing: prospective, randomised, long-term clinical and echocardiographic evaluation. Kardiol Pol, 2006; 64: 1082-1091.

19. Majewski J, Lelakowski J, Haberka K et al. Trwałość stymulacji dwujamowej w długotrwałej obserwacji. Folia Cardiol, 2002; 9: $567-572$.

20. Hauser RG, Kallinen L, Almquist A et al. Comparative clinical performance of atrial and ventricular leads in DDD pacing systems. Pacing Clin Electrophysiol, 1991; 14: 702 (abstract).

21. Helguera ME, Maloney JD, Pinsky SL et al. Long-term performance of endocardial pacing leads. Pacing Clin Electrophysiol, 1994; 17: 56-64.

22. Nery PB, Fernandes R, Nair GM et al. Device-related infection among patients with pacemakers and implantable defibrillators: Incidence, risk factors, and consequences. J Cardiovasc Electrophysiol, 2010; 21: 786-790.

23. van Eck JWM, van Hemel NM, Zuithof $P$ et al. Incidence and predictors of in-hospital events after first implantation of pacemakers. Europace, 2007; 9: 884-889.

24. Udo EO, Zuithoff NP, van Hemel NM et al. Incidence and predictors of short- and long term complications in pacemaker therapy: the FOLLOWPACE study. Heart Rhythm, 2012; 9: 728-735. 


\title{
Efektywność stymulacji przedsionkowej lub przedsionkowo-komorowej w zespole chorego węzła zatokowego w obserwacji odległej
}

\author{
Marcin Kuniewicz ${ }^{1,2}$, Anna Rydlewska ${ }^{1}$, Grzegorz Karkowski $^{1}$, Maria Lelakowska-Pieła ${ }^{3}$, Jacek Majewski ${ }^{1}$, \\ Jacek Lelakowski ${ }^{1}$ \\ 'Klinika Elektrokardiologii, Instytut Kardiologii, Uniwersytet Jagielloński, Krakowski Szpital Specjalistyczny im. Jana Pawła II, Kraków \\ ${ }^{2}$ Katedra i Zakład Anatomii, Collegium Medicum, Uniwersytet Jagielloński, Kraków \\ ${ }^{3}$ Krakowski Szpital Specjalistyczny im. Jana Pawła II, Kraków
}

\section{Streszczenie}

Wstęp: Zespół chorego węzła zatokowego (SSS) to zespół zaburzeń powodujących nieprawidłową częstotliwość rytmu zatokowego, zbyt wolną do bieżących potrzeb fizjologicznych, co prowadzi do wystąpienia objawów klinicznych lub arytmii. Zgodnie z najnowszymi wytycznymi w leczeniu SSS bez zaburzeń przewodzenia przedsionkowo-komorowego (AV), preferuje się stymulację AV (DDD) względem stymulacji przedsionkowej (AAI).

Cel: Celem pracy było porównanie wyników leczenia chorych z wdrożoną stymulacją AAI lub DDD z powodu SSS w obserwacji odległej. Metody: Łącznie grupa badana liczyła 809 osób (463 kobiety, 346 mężczyzn, wiek: 19-95 lat, średnio: 70 土 11 lat). Grupa AAI obejmowała 86 chorych (57 kobiet, 29 mężczyzn, wiek: 19-81 lat, średnio: $65 \pm 15$ lat) a grupa DDD 723 pacjentów (406 kobiet, 317 mężczyzn, wiek: 23-95 lat, średnio: 71,5 \pm 10 lat). Badanie skuteczności stymulacji AAI i DDD w SSS odbyło się na podstawie analizy dokumentacji medycznej chorych poddanych implantacji stymulatora i dokumentacji z co najmniej 3 wizyt kontrolnych. Pierwszorzędowymi punktami końcowymi obserwacji były: reoperacja, zgon, migotanie przedsionków (AF), blok AV.

Wyniki: Średni czas obserwacji wynosił $52 \pm 25$ miesięcy (AAI: $65 \pm 27$; DDD: $50 \pm 24$ ). W grupie AAI na 86 wszczepionych rozruszników 63 (73\%) pozostało bez interwencji. W grupie DDD na 723 wszczepionych rozruszników 661 (91\%) urządzeń nie wymagało interwencji chirurgicznej. W obu grupach badanych zmarło łącznie 105 osób (13\%) — 13 z grupy AAl (15,1\%) i 92 (12,7\%) z grupy DDD ( $p=0,4516$ ). Blok AV w grupie badanej występował średnio po 46,3 $\pm 8,8$ miesiącu po wszczepieniu stymulatora AAI. Rozwój utrwalonego AF zanotowano u 8 (9,3\%) chorych z grupy AAI i u $81(11,2 \%)$ osób z grupy DDD (p = 0,23). Wykazano, że wystąpieniu AF sprzyjają: obecność zespołu tachykardia-bradykardia (HR $=11,31)$ i brak skojarzonego leczenia antyarytmicznego (beta-adrenolitykiem i amiodaronem) (HR = 4,23). Reoperacja dotyczyła 23 (26,7\%) osób z grupy AAl i 62 (8,57\%) pacjentów z grupy DDD ( $p<0,01)$. Operacyjną zmianę trybu stymulacji z AAI na VVI z powodu utrwalonego AF wykonano u 13 (15\%) osób, a z DDD na VVI u $1(0,14 \%)$ chorego $(\mathrm{p}<0,01)$. W pozostałych 47 przypadkach rozwoju AF w grupie DDD tryb zmieniano za pomocą programatora. Ryzyko konieczności doszczepienia elektrody komorowej z powodu AF kształtowało się na poziomie 1,72\%/rok w grupie badanej AAI. Analiza testu log-rank wykazała istotność wypływu rozwoju AF na reoperację w tej grupie chorych $(p=0,0420)$. Powikłania związane z elektrodami zarejestrowano w grupie AAI u $6(6,9 \%)$ osób, a w grupie DDD u 49 (6,7\%) pacjentów (p = 0,94). Czasy do reoperacji różnią się istotnie wśród osób, które mają wszczepiony rozrusznik typu DDD, a tymi, którym implantowano urządzenie typu AAI ( $p=0,0338$; test log-rank). Po 45 miesiącach ryzyko wystąpienia reoperacji w grupie AAI gwałtownie wzrasta i jest spowodowane koniecznością doszczepienia elektrody komorowej.

Wnioski: 1. Stymulacja przedsionkowa jest bezpieczna w SSS, jednak wiąże się z podwyższonym ryzykiem konieczności doszczepienia elektrody komorowej z powodu bloku AV lub rozwoju utrwalonego AF z zaburzeniami przewodzenia AV. 2. Między grupami DDD i AAI nie wykazano statystycznie istotnych różnic dotyczących czasu przeżycia, rozwoju utrwalonego AF, powikłań związanych z elektrodami. 3. Obecność zespołu tachykardia-bradykardia i brak leczenia antyarytmicznego wiążą się z ryzykiem rozwoju utrwalonego AF w obserwacji odległej. 4. Ze względu na większy odsetek reoperacji u chorych ze stymulacją AAl, wynikających głównie z rozwoju utrwalonego AF z bradykardią, zwłaszcza po 4. roku obserwacji, stosowanie układów DDD w SSS może być korzystniejsze. Słowa kluczowe: stymulacja AAI, DDD, chory węzeł zatokowy

Kardiol Pol 2015; 73, 1: 7-16

\section{Adres do korespondencji:}

prof. dr hab. n. med. Jacek Lelakowski, Klinika Elektrokardiologii, Instytut Kardiologii, Uniwersytet Jagielloński, Krakowski Szpital Specjalistyczny im. Jana Pawła II, ul. Prądnicka 80, 31-302 Kraków, tel: +48 1261422 77, faks: +48 1263323 99, e-mail: jlelakow@szpitaljp2.krakow.pl

Praca wpłynęła: 02.11 .2013 r. Zaakceptowana do druku: 10.06.2014 r. Data publikacji AoP: 04.07.2014 r. 